\title{
CLINICAL AND EXPERIMENTAL STUDIES ON OTOTOXICITY OF POTASSIUM BROMATE
}

\author{
SHIGEKI KAMATA, M.D., JIRO HOZAWA, M.D., TAKASHI ISHIDA, M.D., \\ NORIKO KIMURA, M.D. and IZURU NOZAWA, M.D.
}

Department of Otolaryngology, Hirosaki University, School of Medicine, Hirosaki

A case of potassium bromate intoxication showing a severe hearing loss and anuria was reported. This 19 years old female patient had no vertigo nor vestibular disorders, but a strong cochlear damage was suspected by electerochleography. In order to investigate the effects of potassium bromate on the inner ear, the authors performed experiments by using guinea pigs. At first, various concentration of potassium bromate $\left(\mathrm{KBrO}_{3}\right)$ were injected through the guinea pigs peritoneum, and changes of cochlear function were tested by electrocochleography. Then, the animals were sacrified and the inner ear was observed by transmission and scanning plectron microscopy. The animals to which the dosis under $100 \mathrm{mg} / \mathrm{kg} \mathrm{BW}$ was injected, showed no remarkable changes. However, the animals, to which $100-150 \mathrm{mg} \mathrm{BW}$ was given, showed the threshold elevation of $10-30 \mathrm{~dB}$ and the following morphological findings: I) The stria vascularis was affected more severely than Corti's organ. II) Outer hair cells were impaired more severely than inner hair cells. III) Changes of hair cells were more clearly found in the upper turn of the Corti's organ than in the lower turn. IV) Changes of vestibular organ were not found. The animals to which the dosis over $150 \mathrm{mg} / \mathrm{kg} \mathrm{BW}$ was injected, showed no response in electrocochleogram and showed strong morphological changes.

A86-0863-24621

\section{ブロム酸カリウムの聴器毒性に関する臨床的並びに実験的考察}

$$
\begin{aligned}
& \text { 弘前大学医学部耳宜咽喉科学教室（主任：朴沢二郎教授） } \\
& \text { 鎌田重蛼, 朴沢二郎, 石田芓, } \\
& \text { 木村訓子, 野 沢出 }
\end{aligned}
$$

Iはじめに

プロム酸塩（プロム酸カリウム敊よびブロム酸ナトリ ウム)はコールドパーマ第2液として使用されているが

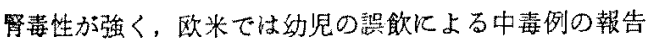
があり，わが国では自獭の目的による中毒例の埌告がみ られている。来た本慗物の中毒症状として聴筧障害を生 することす従来より広く知られているが，実際には列不

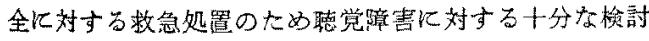
がなされた報告は少ない，今回，われわれは服毒直娞適
切な処置により救命し得た症例の聴力障害について梌索

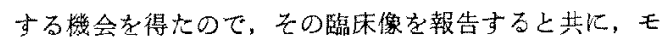
ルモットを使用してブロム酸カリウムの聼器毒性につい

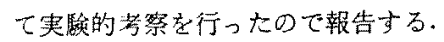

\section{II プロム酸カリウムによる聴覚障害例}

症例: 木○広○19歳, 女, 美容師

主泝: 画側荍聴

既往歴：10歳時飞虫垂切除術を受けた以外特記事項な 
L.

家族璴：特記事項なし

現病歴：昭和55年 2月24日，午娞10時頃自殺0目的で プロム酸カリウム（コールドパーマの中和凪）を約 $50 \mathrm{~g}$ 服用したが30分後佂覀心, 嘔吐が発現, その直後飞某病 院に搬入され胃洗浄等の救急処置をうけた。翌7月25日 より両側耳鳴, 難聴, 頭痛が発現した。7月31日より無 尿をみとめ腎機能検査にて血中 BUN 值, クレアチニン 值の上昇がみられたため某腎センターへ転院，同センタ 一にて6回の血液透析をうけ利尿の回復をみ大が，難聴 は次第火增悪し，辛うじて大声か聞きとれる程度にまで 進行したため精查の目的で弘前大学耳鼻咽喉科を紹介さ

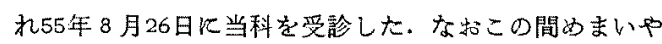
平衡障害はみとめられなかった。

1. 臨床検㚗成綪

1) 耳鏡検㚗所見：雨側鼓膜正常で特に異常はみられ

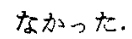

木 $\bigcirc$ 広

5 5. 8. 2.6. (初診時)

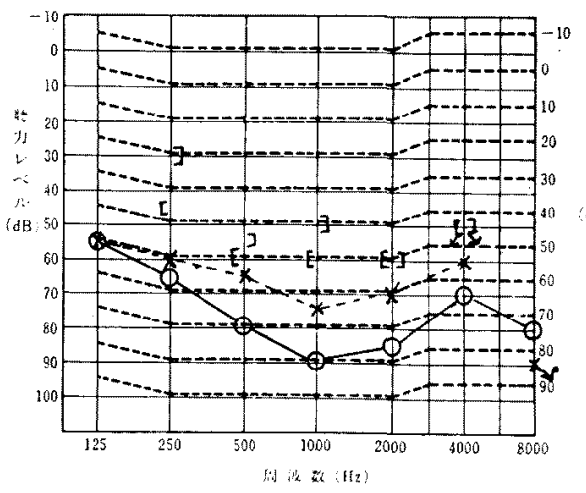

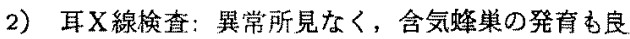
好であった。

3）純音聴力検㚗: 平均聴力レベル右約 $85 \mathrm{~dB}$ ，左約 $75 \mathrm{~dB}$ の水平型感音難㯖が浔められた。（图 1)

4) 自記オージオメトリー：両側共 Jerger II型 (4 $\mathrm{kHz}$ ) を示し，リクルートメント陽性であった。

5）蝸電困検蓇：三举測器製 シグナルプロセッサー 7S11 を用いて外耳道透尊法によりクリック音を使用し $\tau$ Action potential (AP) 閾值を測定したが右的 $45 \mathrm{~dB}$ HL, 左 $55 \mathrm{dBHL}$ であり, 入出力曲線はいわゆる subtractive loss の内耳障害型を呈した。四2は右耳の成績 を示すが左耳同様の所見であった，(図 2)

6)平衡機能検査: 自発及び頭位眼振は認められず温 度眼振検查，回軽検榃，視運動性眼振検查及び示標追跡 模㚗はすへて正常であった。

7）脳神経学的検查：第证神経以外飞特に所見は見 れなかった。

木○広 ○ 56. 6. 4 .

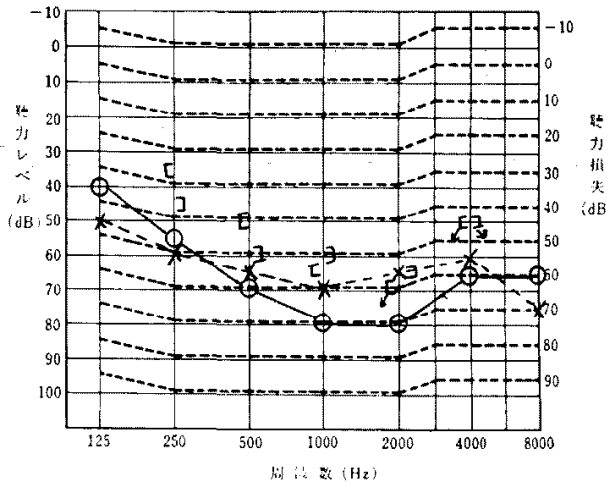

図 1 症例のオージオグラム ( $\mathrm{dB}$ : 㯖力レベル)
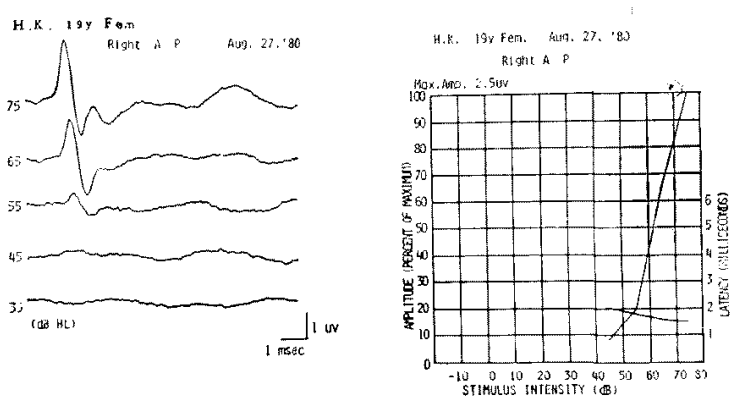

図 2 症例の蛤需図 (右耳) 

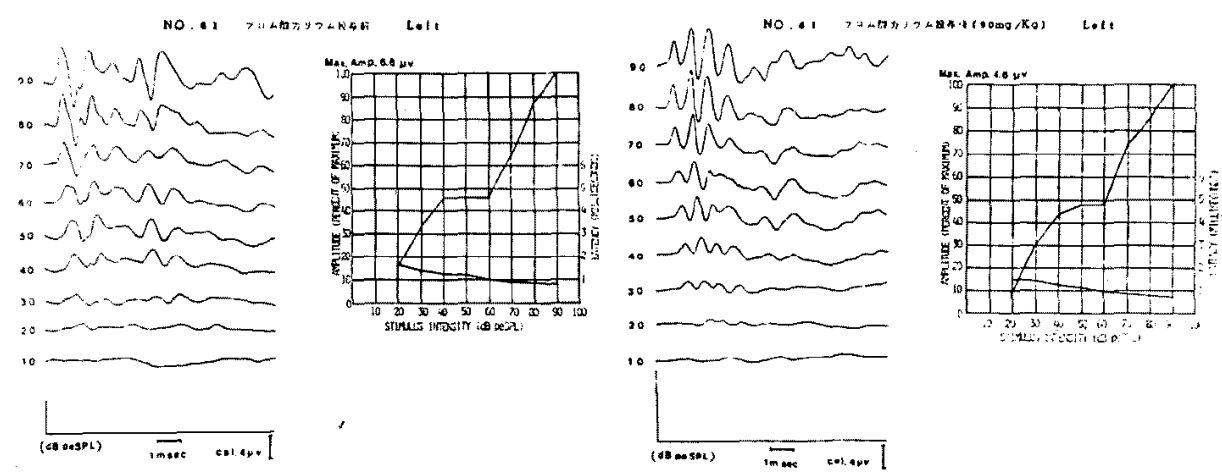

图 3 第 1 群動物のプロム酸カリウム投与前後の蛤電図
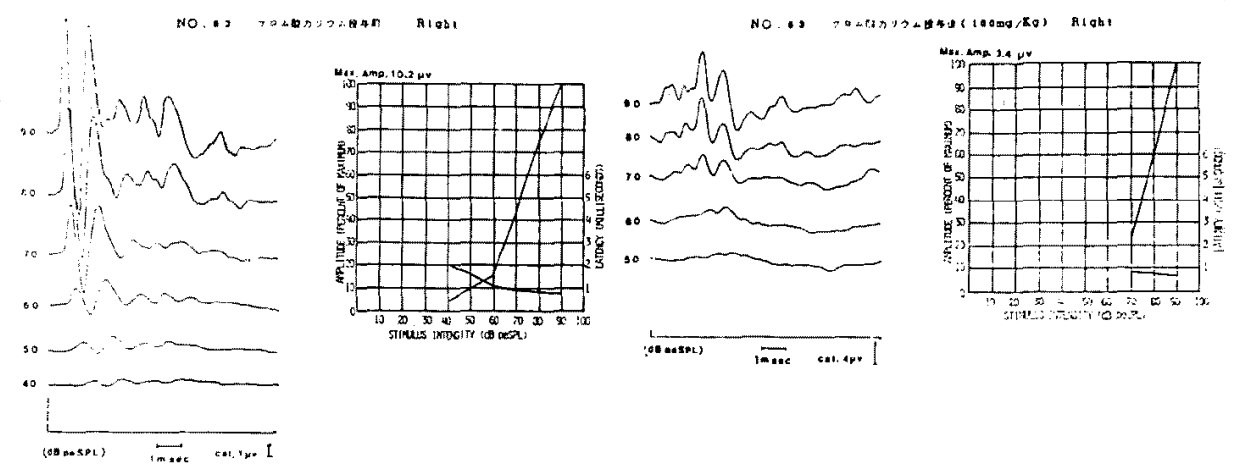

図 4 第 2 群動物のブロム酸カリウム投与前後の蛸電図

\section{2. 難㥁の経過}

本症例山当科受䛦後, ビミタン刜, ATP 製郕等の内 服を行いつつ経過を観察したが，耳鳴（特に右耳）在諗 めるものの，図1右に見られるごとく難㯖の進行はな く、觜センターにおける腎機能杼査成綪でも悪化はみ上 められなかった。ただし、嚾㯖によって日常生活や会話 等炕支障をさたすので，補聴器を装用しながら美容師と して復職し，現在に至っている。

\section{3. 墡覚障害の特徽}

本症例仁見られた噹党障害の特徽を列記すると。

1)再側性であり, 障害の程度は高度でかつ左右略同 程度であったこと。

2）低，中，高音域のいずれにむ障害があり水平型才 ージオグラムを呈したこと。

3）補充現象陽性であり，蝸電图所見よりも内耳障害 が䓔えられたこと。

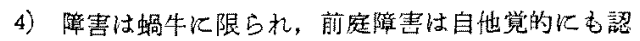

められなかったこと。

5）難聽の程度は障害をうけた時点で固定しその後の 進行が認められなかったこと。

等があげられる.

\section{II ブロム酸カリウムの聴器毒性に関する実験的考察}

前述の症例に認められたブロム酸力リウムによる聴器 毒性の病態を解明するため，モルモットを使用して以下 のごとく実硔を行った.

\section{1. 実験方法}

実駼刘象として，体重 $300 \mathrm{~g}$ 前後のプライエル反射正 常の白色モルモット20匹を使用し，ブロム酸力りウム

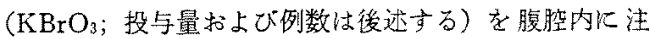
射した。

聴觉障害に関しては，ブロム酸カりウム投与前および

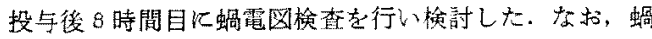
電図は針電極を用いて外耳道より誘導し，刺激音はクリ 
ックをスピーカー一より与え三栄測測器製シグナルブロセ ッーTOZ型によ 潜時，最大振幅范苔録した。

プロム酸カリウム投与後の螎電㡰を記録した後，プラ

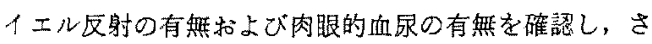
らに断頭して以下のごとく内耳の抢怒学的恤化を観察し た.まず, $2.5 \%$ ダルールアルデヒド・リン酸液 ( $\mathrm{pH}$ 7.4）にて全身篧流を行った娞，断䫒し，才みやかに中 耳骨胞を開放してさらに局所の固定を行った. その後蝠 牛を採取し，各梄本の左側を $2 \%$ タンニン酸叔よび $2 \%$ オスミゥム酸にて後固定䘮行った後，上昇エ夕ノ一儿系 列に上る脱水，酷酸イソアミンによる置換，臨界点乾燥 を行い，金とコーテングして走查型電子顕微鏡（JSM25 S II ) Kて観察した. 一方右側瀜牛は $2 \%$ オミウム 酸で後固定した後上型エ夕ノ一ル系列による脱水, Epon 312 包埋を行い, 超薄切片を作製した. さらKウラン・

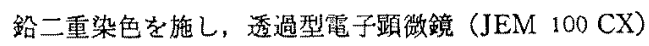

飞観察した. この祭,トルイジンブルー染色を行っ

て，光学頙徽鏡による観祭も行った。

2. 実駼成精

プロム酸カリウムの投与疅は表 2 示すごとくであ り，これを以下の3群に大別して形熊学的变化を比较梌 剖した。すななら $100 \mathrm{mg} / \mathrm{kg}$ 未満投与例を第 1 群( 5 匹)， $100 \sim 149 \mathrm{mg} / \mathrm{kg}$ を第 2 群( 6 匹)，150 $\mathrm{mg} / \mathrm{kg}$ 以上を第 3 群(9匹)とした。

a. 第 1 群 ( $\mathrm{KBrO}_{3} ; 100 \mathrm{mg}$ 末渵投与群)

この群の投与前㣪の䖮電困は図 3 に示すごとくであ り, $\mathrm{APN}_{1}$ の域值, 潜時, 入出力曲線化 $\mathrm{KBrO}_{3}$ 投与前後 の変化は諗めなかった。また肉脹的血尿むこの群では見 られなかった，形䔮学的にも变化は軽度であり，走查型

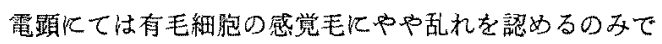

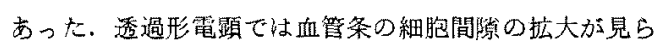
れたが，その他に著明な变化を侨めなかった（图 3）

b. 第 2 群 $\left(\mathrm{KBrO}_{3} ; 100 \sim 149 \mathrm{mg} / \mathrm{kg}\right.$ 投与群)

この群の投与前後の螎電图は四4亿示すように，投与 後の $\mathrm{APN}_{1}$ の振愊減少と共に, 約 $30 \mathrm{~dB}$ の域值上昇市

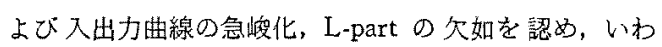
ゆる subtractive loss pattern を呈した（圂 4) 肉瞍

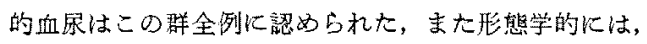
光顕にて血管条辺縁細胞の变性が諗められた，走查型電 䫓標本で㑔回転括よび第 3 回転の障害が下方回枟より む高度であった，すなわち四５亿示すごとく頂および第 3 回忶に战いては外有毛細胞，特飞笨 3 列目の障害が強
く，感觉毛の乱れ，融合あるいは一部脱落が認められ た.この障害は第2 列目，第1列目になるにつれて㹩店 となり，また内有毛細胞は感党毛の乱れは認めるが，外 有毛細胞よりす障慧は軽度であった。第 2 回転, 基底回 轱になると, 外有毛細胞の障害む軽度となり, 第了列目 の感觉毛化やや乱机認める程度であった（図 5) 一 方，透過型電顕標本ではコルチ器よりも血管条特に辺縁

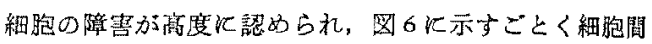
䣣の㹡大のみでなく，細胞汃らの突出物やミェリン様小 体の出現, ミトコンドリアの变性, 空胞形成等が見られ た.（図 6）これらの桨化すやはり上方回転注と高度な 傾向が認められ，基咸回転ではその変化は軽销であっ た.

c. 第 3 群 $\left(\mathrm{KBrO}_{3} ; 150 \mathrm{mg} / \mathrm{kg}\right.$ 以上投与群)

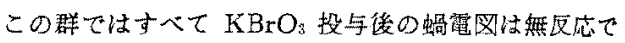

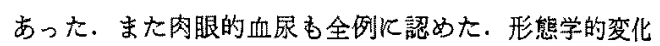
は图7に示すごとく全体的に第 2 群よりさらに高度とな り,内リンバ腕の collapse が認められ（园 7), 走查型 電頙殹本にて傎回転の外有毛細胞, 特第 3 列目の感党 毛はかなり毛束か眯になっているのが観祭された。また 基底回転でも融合が認められ障害は上方回転のみでなく 下方回転にも及几でいた。なお，一部の標本てはライス ネル膜の内リンパ舼への陥凹が著明となり, 走查型電䫓 にて有毛細胞の観祭方困難なものも見られた.

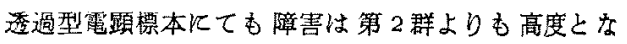
り，上方回転のみならず下方回転にも空胞化，ミトコン ドリアの变性等が認められた。

以上の变化を $\mathrm{KBrO}_{3}$ の投与量と螖牛回別の两面よ り比較してまとめたものが表1である。また投与量別に

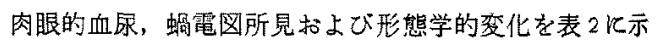
した. (表 1，2)

\section{V 考 按}

ブロム塩酸の中毒症例を1941年 Carratala放が初め て報告して以来，内外江怙いていくつかの報告加胃られ

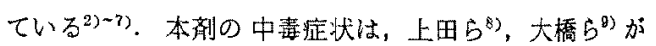
述べているごとく，1）督障書（血㽷，乏尿，無尿），2）

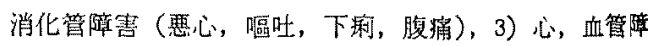
害 (血珐低下, 角血)，4）㯖覚障害 (難㯖, 耳鳴)であ り内科, 泌尿器科比ける報告が主である。外国では主 に幼児の愦飲に上る中毒例であり，我加园に执いてはは とんどが目杸の目的で服毒した例である．塄賞障害につ

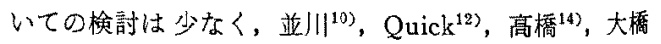


表 1

ブロム酸カリウム投与後の各回枟別の形热学 的变化

\begin{tabular}{|c|c|c|c|c|c|c|c|c|c|}
\hline & \multicolumn{3}{|c|}{ 策 3 解 } & \multicolumn{3}{|c|}{ 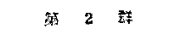 } & \multicolumn{3}{|c|}{ 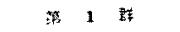 } \\
\hline & \multirow{2}{*}{ lik } & 046 & & \multirow{2}{*}{ we } & in $\mathrm{C}$ & \multirow{2}{*}{$: 4$} & \multicolumn{3}{|c|}{$0: 16$} \\
\hline & & 123 & & & 123 & & & 123 & \\
\hline 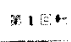 & 0 & & & Q & & 0 & 0 & 1000 & $\mathrm{O}$ \\
\hline $42=2$ & 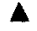 & $\boldsymbol{\Delta} \boldsymbol{\Delta} \boldsymbol{A}$ & O & 0 & $\otimes \otimes C$ & 0 & 0 & 000 & 0 \\
\hline अ $3 E E$ & (8) & & 0 & 0 & $\otimes \otimes \otimes$ & 0 & 0 & 000 & 0 \\
\hline wat & $\otimes$ & & & 0 & 000 & 8 & 0 & 1000 & $\mathrm{O}$ \\
\hline
\end{tabular}

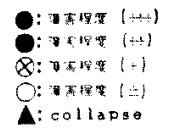

表 2 薬物投与量と障害の程度の関係

\begin{tabular}{|c|c|c|c|}
\hline 投与量 所自 & $\begin{array}{l}\text { 肉眼的 } \\
\text { 血疗 }\end{array}$ & 蛤電図 & $\begin{array}{l}\text { 形態学的 } \\
\text { 姿化 }\end{array}$ \\
\hline $\begin{array}{l}\mathrm{KBrO}_{3} \\
100 \mathrm{gm} / \mathrm{kg} \text { 以下 }\end{array}$ & $(\rightarrow)$ & 恋化なし & 变化应L \\
\hline $\begin{array}{l}\mathrm{KBrO}_{3} \\
100-150 \mathrm{mg} / \mathrm{kg}\end{array}$ & $(+)$ & $\begin{array}{l}\text { Subtractive } \\
\text { loss パターン }\end{array}$ & 中等度障害 \\
\hline $\begin{array}{l}\mathrm{KBrO}_{3} \\
150 \mathrm{mg} / \mathrm{kg} \text { 以上 }\end{array}$ & $(+)$ & 無 反志 & 高度障害 \\
\hline
\end{tabular}

15）等の報告を見るのみである。

松元 ${ }^{11)}$ Kよると外国では薬凨が希釉液であり，しか も主に幼児の誤飲例であるため聴力障書が把握しにく く，こ机に対して我が国ては自殺のための大量服用例で ある関係上，難聽例が多いとしている。また，服用量に ついては，予後の如何に加からず 15〜25gの例が多 く，薬浏服用が難聴発現までの時間は 4〜16時間で目 覚された難㯖が急速に高度に進行するとしている，同様 K大橋 ${ }^{15)}$ の例でも服用後 3 時間で難㯖を自喾, 12時間後 には䁄力はほとんど消失したと報告している。

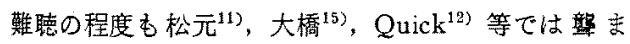
たは高度難㯖例が多く蝸電図所見でも，大橋の例では全

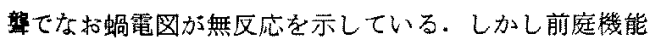
が障害された例報告されていない，著者らの例も諸家 の報告とほほ一致し, 雨側高度の感音難聴であり，䖮雪 図検查により内耳障害であることが推測された。しかる 障害沙蛤牛のみ几限られ前庭機能の障害山認められなか

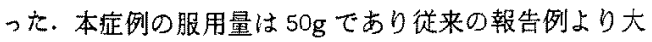

量であったが．胃洗浄等の適切な処置により実際に体内 に吸収された量はこれよりも少なく，そのため全格に 至らなかったものと思われる。

ブロム酸塩により聴覚器の障害されるメカニズムは末

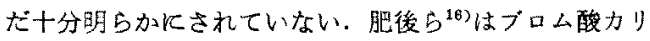
ウム投与モルモットの CM (cochlear microphonics) を測定し，有毛細胞が基底回耺より濑次障害されて行く であるろと推測している.これ亿対して松元"1は CM， EP (endocochlear DC potential)を指標とする電気生理 学的および組織学的检索により，まず血管条が障害され て内リンパ液の組織に变化が括こり，次にラセン器に作 用して外有毛細胞が障害されるであるうと推論してい

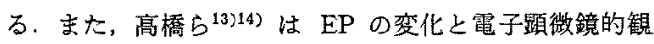
察の結果より血管条の变化が辺縁絗胞の变性飞初まり内 リンバ空の collapse 状態を形成するとし，障害の程度 には個体差も大きく関与するが，同一螖牛に括いては血 管条辺縁細胞の方が有毛細胞上り受燳性が高く，回転别 にみると基底回転，第 2 回転の変性が著明で，上方回転 ほ上形態学的变化は柽度となり，外有毛細蚫の方が内有 毛細胞より障害されやすいと述べている。

郎害の程度に動物による個体差のあることは著者 実験成績でも明らかであるが，ブロム酸カリウムの投与 舅と内耳障害との間汇密接な関係があり，モルモットで は投与量 $100 \mathrm{mg} / \mathrm{kg}$ を越えると降寒が登現することが 今回の実駼により判明した。すなわら $100 \mathrm{mg} / \mathrm{kg}$ 以下

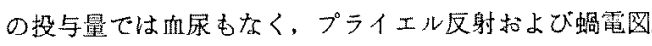
はほほ正常で，電顕観察で屯血管条の細胞間隚のわず加 な拡大を兒る以外特に閔題視する形態学的所見は得られ なかった．これに対し $100 \sim 149 \mathrm{mg} / \mathrm{kg}$ の投与群では血

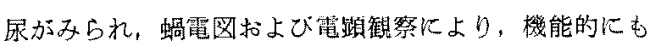
形態学的飞毛内耳障害が認められている。更飞投与量を 增加し $150 \mathrm{mg} / \mathrm{kg}$ 以上投与した群では全敬となり，形 熊学的化も，上り高度の障害を䍿めている。

薬物により㯖器が障害される様式には，カナマイシン

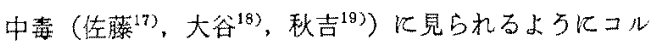
手器有毛細胞が先傽害される形式とエタクリン酸, フ

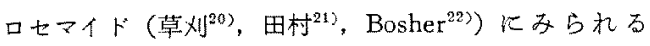
ような血管条が先に障害される形式と2つに大别きれる がブロム酸カリウムの場合は後者に近い委のであり，且 管条の辺縁細胞の变性飞始まり，その結果，蝸牛管の collapse が見られ，内リンパ組成の変化がコルチ器有毛 細胞に障害を及ほすすもの上推側さ机る。しかし有要細胞 の障害が外有毛細胞に強く胃られることは促来の聴器毒 
の場合と同様であったが，外有毛紬胞の障害が第 3 列に 抬いて最娄強く，第 2 ；第1列で軽度になるという点，

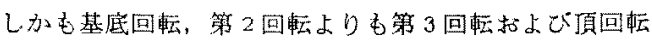
儿去いて強い障害が見られるという点はカナマイシン中

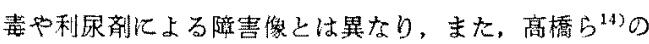
報告とも異なる結果であった。これは使用した薬剂が力 リウム程であるか、ナトリウム㙁であるかの化学棈造上 の差異によるものか，あるいはブロム酸カリウムの場 合, 促来の聴器毒とは異なった筆 3 の障害形式をとる蒋 物であるのか更に詳稩な检討を行う必要があると思わ机 た.

\section{ま と め}

1)自殺の目的でブロム酸力リウムを服用したが適切な 処置に上り救命し得た19歳女性の橲觉障害について報告 した，その特徽は次のごとくであった。

i）両倒高膂の障害であり，左右ほほ同程度であった。

ii）低，中高音域のいずれにも陪宰があり純音オーシ オグラム惊水平型を示した。

iii）補充現象陽性でちり，蝸電图检査でも内耳障害の パターンを示した.

iv）難㯖の程度は障害をうけた時点で固定し，その後 の進行は認められなかった。

v) 障害は蜛牛飞限られ，前庭器の障害は自他覚的に あ認められなかった。

2) ブロム酸カリウムによる聴器陪害のメ力ニズムを知 る目的でモルモット20匹を使用して实験的考察を行っ た、すなるち，モルモットをろ群行分け，I群に怯 100 $\mathrm{mg} / \mathrm{kg}$ 以下, II 群儿洁 $100 \sim 149 \mathrm{mg} / \mathrm{kg}$, III 群化は 150 $\mathrm{mg} / \mathrm{kg}$ 以上をそれぞれ腹腔内に注射し，血尿の有無， 注射前後のプライエル区射の有無，蛤電图所胃の变化を

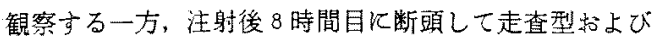

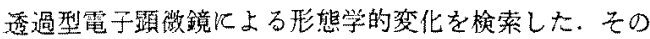
秚果,

i）ブロム酸カリウムと㯖器障害との閒に密接な関倸 があり，100 $\mathrm{mg} / \mathrm{kg}$ 前後に障害域值の存在すること が判明した。すなわち，第I群では機能的にも形態 学的にも变化法晃られず，I群では機能的和よび北

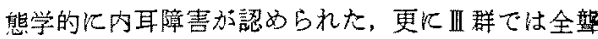
を示し，形態学的变化も高度ですった。

ii）内耳障害は血管条の辺縁稩胞の变性に始まり蜳牛 管の collapseをきたし, 内リンパ組成の変化が有 毛細胞に障害を及任すむのと推測した。 iii）有毛細胞の障害形式は外有毛細胞の第 3 列目に强 く，第 2 列，第 1 列になるに従って軽微であった。

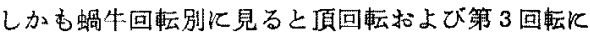
おいて障害が強く，第 2 回転，基底回転の方が軽度 であった。

iv）この上うな内耳の障害形式はアミ／配楉体抗生物 質火よる障害や，エタクリン酸，フロセマイトKよ る障害の形式と翼なるむのであり，今徭更に詳細な 㭲索が必要であるうと思われた。

\section{参 考 文 朝}

1) Carratala $R$ and Uracaray L: Grave intoxication due to ingestion of potassium bromate. Rev Asoc med argent 55: 529, 1941. (Amer J Dis Child 74: 730, 1947.より引用)

2) Dunsky I; Potassium bromate poisoning. Amer $J$ Dis Child 74: 730-734, 1947.

3) Kitto W and Dumars KW: Potassium bromate poisoning. J Pediat 35: 197-200, 1949

4) Parker W A and Barr J R: Potassium bromate poisoning. Brit M J 1: 1363, 1951 ,

5) 和田一郎 他: 臭菜酸塩中毒による急性㹂不全の1 侧 監泌 23: 37-42，1969.

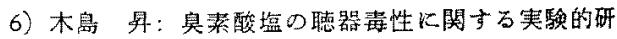
究 日大医学雑誌 37: 1057-1068，1978.

7)浅朴悎 他：腹膜透析法に上るブロム酸カリウム （コールドー゚ーマ第2 液）中毒による急性腎不全の 1 治験例，ベリソリタ交献集第 2 報、41.

8）上田英雄 他：プロム酸カリウム（コールドハーマ

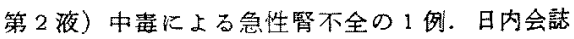
54: 1408-1414, 1966.

9）大攜伸正 他：真萃カリウム（コールドパーマ第 2 液）中敏に上る急性繁不全例。

10）並川清一：ペーマネント花内服に上る高度難聴の店 例 日耳奥 61: 333，1958。

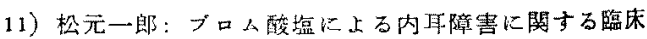
的ならびに実瑍的研究。耳鼻 19:220-236，1973.

12) Quick C A: Deafness and Renal Failure Due to Potassium Bromate Poisoning Arch Otolaryngol 101: 494-495, 1975.

13）高括政見他：ブロ么酸塩投与に上る血管案の变化

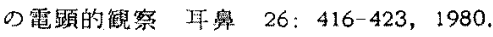

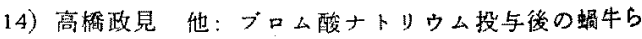



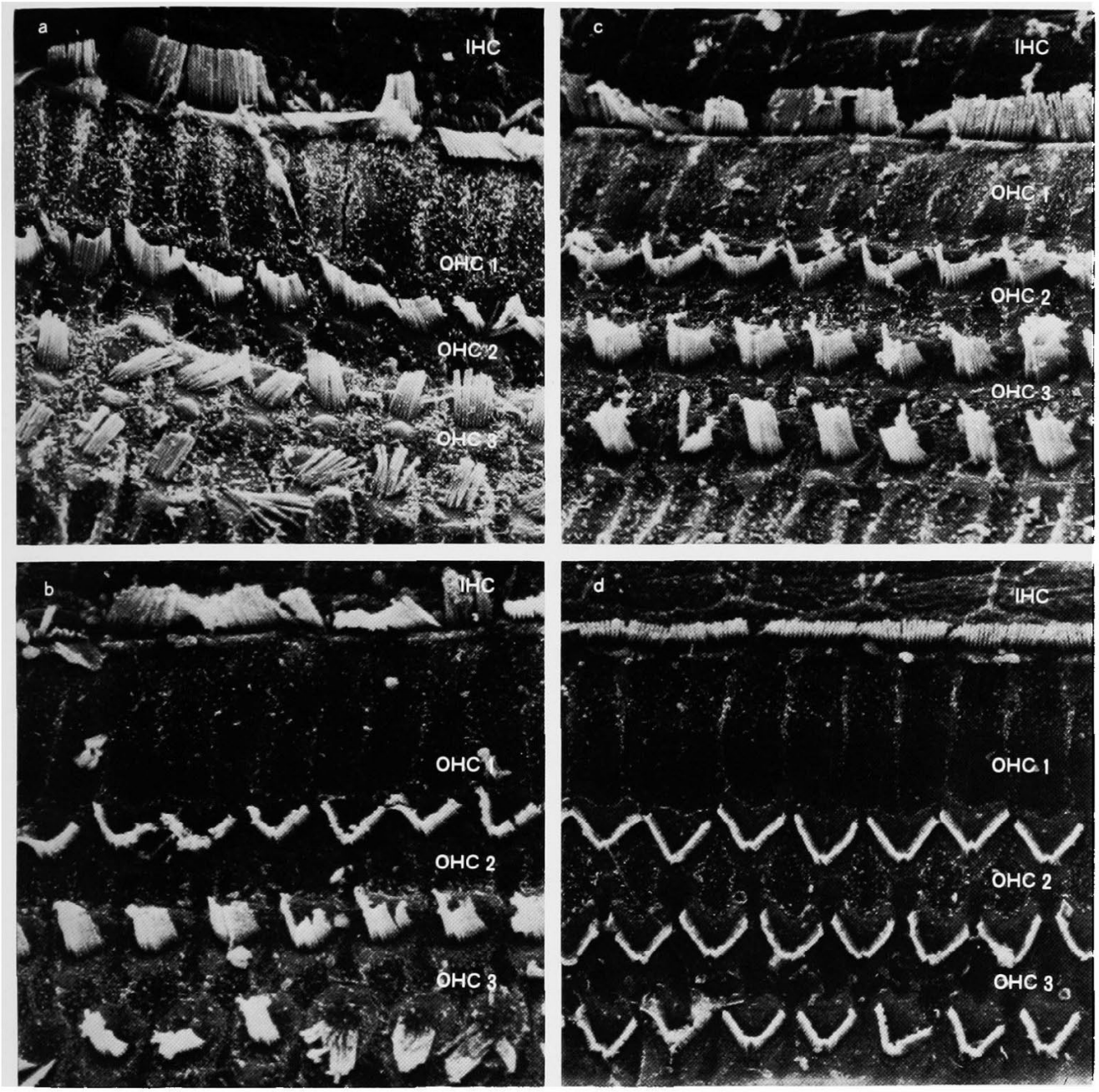

図 5

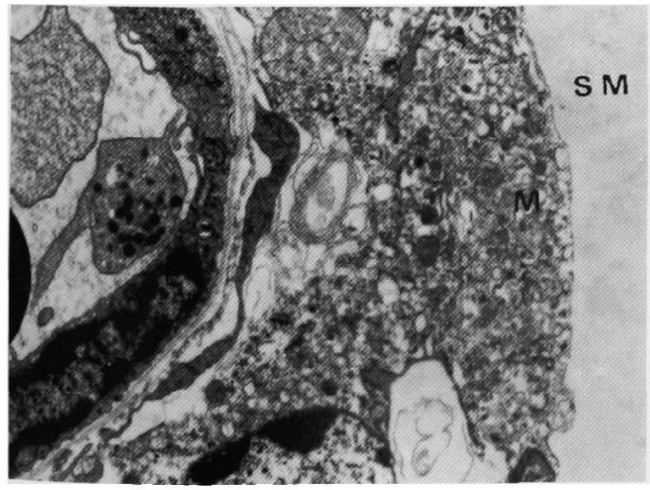

図 6

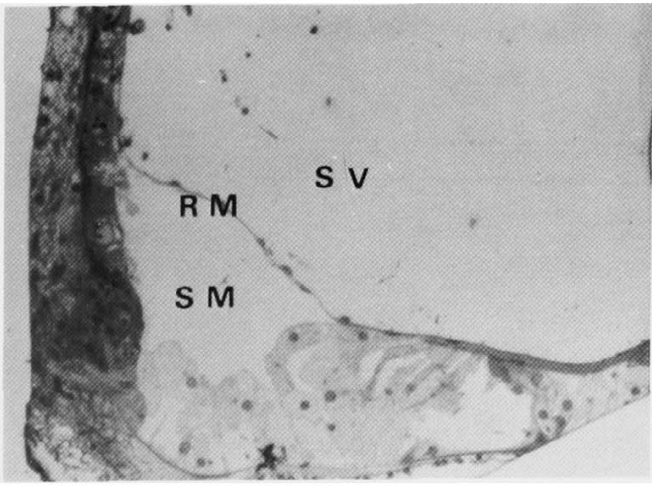

図 7 
せん器の電顕像. 内兮生化学 11：66-68, 1981.

15）大橎徽他：プロム酸ナトリウム（コールドパー。

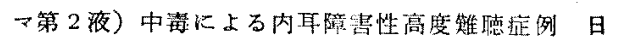
耳粤85: 41-45, 1982.

16）盵後晃他：プロム酸カリ（コールドバーマ用） の中毒例 日内会誌 46: 1221，1957．

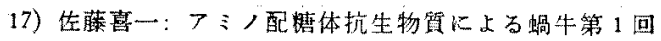
転下端部ラセン器の变化に関する走查電子顕微鏡学 的研筑 耳 26: 589-607，1080.

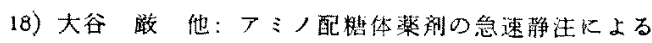

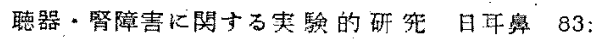
1482-1490, 1980.

19）秋吉正豊 他: フロセミド投与比上るアミノ配精体 抗生物賀の聴器障害の增强の譏序について 内耳生 化学 11: 149-151，1981.

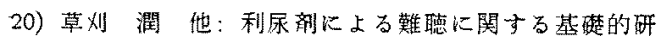
究 Audiology Japan 21：117-122, 1978.

21）田村秀明：エタタリン酸蛙上びフロをマイドに上る 内耳障害の発生機序比閣与る組艀化学的研究 Audiology japan 21: 668-687, 1978.

22) Bosher S K et al: The effects of ethacrynic acid upon the cochlear endolymph and stria vasculalis. Acta Otolaryng 75: 184-191, 1973.

本論文は第82回日本耳臿㸶㬋科学会総会，第16回国際 オージロジー会議（ヘルシンキ）に括いて発表した。

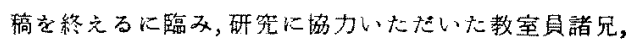
本学電子顕徽鏡室三上昭统，対馬良和雨氏に樑く感謝い たします。

(原嗃受付 昭和 58，3，22日）

别刷請求先 $=036$ 弘前方在府町 5 弘前大学医学部耳壆㸶喉科学教室鐮田重蛼

\section{付図説 明}

図 5 走查型電子䫓微鏡所見(第 2 群蝸牛所見)

a. 項回転 $(\times 1500)$

外有毛細胞（OHC），特海第 2，3列目の感賞毛D 乱れ，一部脱落が琵められる。内有毛細胞 (IHC) は一部に感覚毛の乱れを認める。

b. 第 3 回転 $(\times 1500)$

外有毛細狍 $(\mathrm{OHC})$ ，特に第 3 列目の感覚毛に乱れ， 融合が認められる。

c. 第 2 回転 $(\times 1500)$

外有毛細胞 $(\mathrm{OHC})$ 第 3 列目の一部化感觉毛の乱れ を認るるが，上方回転よりも障害は怪度てある。

$\mathrm{d}$. 基底回転 $(\times 1500)$

外有毛細胞 (OHC)，内有毛細胞（IHC）共化感賞 毛はかなり度く保たれている。

IHC：内有毛緗胞

$\mathrm{OHC} 1$ ：外有毛細胞第 1 列

$\mathrm{OHC} 2$ : 外有毛細胞第 2 列

OHC 3: 外有毛絽胞第 3 列

図 6 第 2 群動物の血管条（透過電顕像） 辺縁細胞の著明な变制を認める。

$$
\begin{aligned}
& \text { (電子染色 }(+) \times 10000) \\
& \mathrm{SM} \text { ：中央階 } \\
& \mathrm{M} \text { ：辺縁細胞 }
\end{aligned}
$$

図 7 第 3 群動物の蝸牛（光䩀像） 血管条の夜性，ライスネル膜の陥凹を認める。 (HE染色)

$S V$ ：前底階

SM : 中央階

$\mathrm{RM}$ : ライスネル膜 